\title{
Corporate Taxation and the Impact of Governance, Political and Economic Factors
}

\author{
Marcel Gérard \\ Fernando M. M. Ruiz
}

CESIFO WORKING PAPER NO. 2904

CATEGORY 1: Public FinANCE

DECEMBER 2009

Presented at CeSifo Area Conference on Public Sector Economics, April 2009

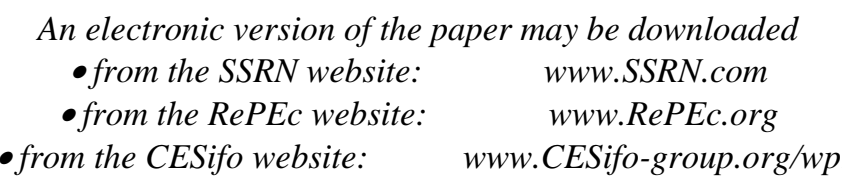




\title{
Corporate Taxation and the Impact of Governance, Political and Economic Factors
}

\begin{abstract}
In this paper we first use two international data sets to investigate how governance, political and economic factors influence corporate tax rates. We show that institutional and political factors matter: good governance reduces the tax rate; a parliamentary system, especially a plurality election system, and religious or nationalist executives too, push tax rates upward. Traditional variables also matter: economic openness has a negative effect on tax rates although market size has a positive one. Though it is not robust, interaction among neighbors also plays a role. Then we turn to theory and extend a standard model of tax competition to provide a channel for the elements set forth so far to influence tax rates formation; nested in the economic theory of lobbying that exercise provides our empirical investigation with theoretical foundations.
\end{abstract}

JEL-Code: H73, H70.

Keywords: institutions and taxation, tax competition, lobbying.

\author{
Marcel Gérard \\ Catholic University of Mons, FUCaM and \\ Catholic University of Louvain \\ Chaussée de Binche 151 \\ 7000 Mons \\ Belgium \\ marcel.gerard@fucam.ac.be
}

\author{
Fernando M. M. Ruiz \\ Royal Military Academy \\ Brussels \\ Belgium \\ fernando.ruiz@rma.ac.be
}

December 23, 2009

We are especially grateful to Rémi Colliat, Pablo D'Erasmo, Michael Devereux, Nelly Exbrayat, Marco Runkel and participants to conferences and seminars in Munich (CESifo), Toronto (CEA), Milan and Grenoble for their helpful comments and suggestions. 


\section{Introduction}

Empirical research on corporate tax rates formation usually relies on interdependence among jurisdictions and on economic variables like differences in country size, budgetary needs, openness to international investment and multinational firms, and on core-periphery arguments. Similarly, theoretical models privilege tax competition, or possibly yardstick competition, along a two step game: in the first step governments fix the tax rates and in the second one firms decide on the allocation of investment and taxable profit accordingly. In this paper we expand the set of potentially explaining variables and include them in the empirical analysis below; then we revise the supporting theoretical model adding a preliminary step where governments are lobbied by the firms.

The main issue in this paper is whether governance, political and economic factors influence the corporate income tax rate. Indeed, next to the classical determinants of tax and yardstick competition based on the influence of tax rates in neighboring countries, a number of economic and political factors might be at work, including good governance and political orientation.

To take an example, a century ago, in 1909, the US decided to introduce a corporate income tax at a rate of one per cent. ${ }^{1}$ That rate went up and down during the next one hundred years, but a characteristic of the up jumps is that they were mostly carried out during periods of war or of crisis, like the World War I, the Great Depression, the World War II, the Korean War and the Vietnam War; then additional taxes were introduced and in some cases later integrated within the regular rate. In some sense, it can be observed a kind of ratchet effect. ${ }^{2}$ The corporate tax rate increased during periods when political events limited the participation of the people to the decisions of the government as well as the downward pressures of lobbying groups. However, in periods of usual business, when lobbying groups are presumably at work, the corporate tax rate followed a slow decrease.

More generally we want to examine whether and how governance and political factors might be important determinants of the corporate tax rate. Regarding the former we adopt the definition of the World Bank and we interpret governance as institutional quality.

Our empirical results show that, next to economic factors, institutional and political factors do influence the corporate tax rate. Especially we find

\footnotetext{
${ }^{1}$ See IRS (2002).

${ }^{2}$ See for instance Hindriks and Myles (2006), page 82 .
} 
that good governance reduces the corporate income tax rate, and that a parliamentary system, especially plurality election, and religious or nationalist executives increase that tax rate. In a sense our results are in line with Campos and Giovannoni (2008) who finds empirical evidence that "firms that favor lobbying tend to be in countries that are less politically unstable, more democratic, with more independent media, and which have experienced more political leadership alternations. Moreover, they are also more likely to be located in federal states, with presidential systems and, within presidential systems, where the president has fewer powers. Within parliamentary systems, lobbying seems to be more effective where there are more constraints on the executive". In other words, the political and institutional factors that we find significant in our study could be interpreted as instruments for the presence of lobbies in a country. We use that possible link to construct a discussion and an explanation of our empirical findings.

To the best of our knowledge, no paper so far has studied empirically the link between the corporate tax and governance and institutional factors. However some papers argue for a greater debate, or more democracy, on the issue of corporate taxation (see Ganghof and Genschel, 2007) and Li (2006) tries to observe the political causes of tax incentives. ${ }^{3}$

In general, on the empirical side, the link between political variables and the corporate tax has not been clearly established. Most articles studying tax interactions find no or little relation between the tax rate and the right or left orientation of the government (see Gomes and Pouget 2008, Devereux, Lockwood and Redoano, 2008). That result contrasts with the papers claiming an association between ideology and fiscal preferences (see Tavares 2004). ${ }^{4}$

Economic factors are now standard in the literature aiming at explaining the corporate income tax rate, especially in the empirical studies based on the theoretical tax competition literature which is sharply increasing since the 80's (for a survey, see Wilson, 1999). Among those contributions we can mention Slemrod (2004) which sets forth the negative link between openness of an economy and the corporate income tax rate, as well as Rodrik (1997), Swank and Steinmo (2002) and Winner (2005). Finding a positive link between those variables or no relation at all are Quinn (1997) and Garrett

\footnotetext{
${ }^{3}$ He studies the link between democracy, autocracy and tax incentives to FDI. However, he bases his argument on the reduction of business costs through the respect of the rule of law and better democratic institutions, and not on the link between those variables and the presence of lobbying groups.

${ }^{4}$ Let us add that Hahm et al. (1995) do not uncover a clear correlation between party's idelogies and public deficits.
} 
(1998) respectively. Our results clearly support Slemrod view.

Other articles have found that the corporate tax rate of neighboring countries is the main determinant of the tax rate. They estimate tax reaction functions suggested by the models of yardstick or tax competition (see e.g. Brueckner, 2003). Typical of those models are Devereux, Lockwood and Redoano (2002, 2008), Redoano (2003), Altshuler and Goodspeed (2002), Besley, Griffith and Klemm (2001), Ruiz and Gérard (2008), Cassette and Paty (2008), Crabbé and Vandenbusshe (2008), Gomes and Pouget (2008). ${ }^{5}$ Our results show some support for tax interdependence, but the findings are not robust with respect to the specification of the model.

Although the results obtained in the empirical investigation are interesting per se, they lack of theoretical foundation. Therefore we complete the empirical exercise with a theoretical analysis. Standard models of tax competition like that used by Gérard (2007), provide a theoretical support for tax interdependence and the influence of economic variables like the size of the country and the degree of openness. However channels for the other variables set forth in our empirical exercise are missing; they have to be suggested and incorporated in the theory. This is the reason why we expand our model of tax competition in order to allow for a channel reflecting the action of those variables. We conduct that extension using the seminal work of Grossman and Helpman (1994), which refers to Bernheim and Whinston (1986), an approach also used by Conconi (2003), as well as by Marceau and Smart (2003) and by Mahle and Runkel (2009); alternatively we also follow Lorz (1998).

In section 2 below, we propose a broad discussion of how governance, political and economic factors may influence the corporate income tax. Section 3 is dedicated to our empirical investigation: we present our data set; we report on our empirical exercise first estimating a panel data without spatial lags, then taking into account the tax rates in neighboring countries. In section 4 we turn to the theoretical exercise, suggesting a model which both reinterprets and enlarges standard modeling in the field. Finally, Section 5 provides some conclusions.

\section{Governance, political and economic factors}

In this section, we propose a broad discussion of how governance, political and economic factors respectively, may influence the level of the corporate income tax rate.

\footnotetext{
${ }^{5}$ For more references see Ruiz and Gérard (2008).
} 


\subsection{Governance and institutional quality}

There is no unique definition of governance in the literature. Here we interpret governance as "institutional quality" and more particularly we adopt the definition of the World Bank.

The Worldwide Governance Indicators (WGI) project of the World Bank defines governance as "the traditions and institutions by which authority in a country is exercised. This includes the process by which governments are selected, monitored and replaced; the capacity of the government to effectively formulate and implement sound policies; and the respect of citizens and the state for the institutions that govern economic and social interactions among them" (see Kaufmann, Kraay and Zoido-Lobatón, 1999, and the World Bank).

Measuring that broad concept is difficult. However, there are different types of data which are informative or can be interpreted as proxies to evaluate "good" governance. For instance, the WGI provides six dimensions of governance: Voice and Accountability, Political Stability and Absence of Violence, Government Effectiveness, Regulatory Quality, Rule of Law, and Control of Corruption. ${ }^{6}$

Those indicators might reflect, in a way, the strengths and weaknesses of the democratic process. As pointed out by Hirst (2000), "Democracy is valuable in this context if it provides legitimation for good governance. Multi-party competition and free elections are valuable in preventing cronyism and corruption, and in building public support for development strategies, but only if parties eschew extremism and play the political game by the appropriate liberal rules". In other words, the form of democracy which prevails in western economies may provide a support for good governance.

For Campos and Giovannoni (2008), a priori, "stronger democracies have stronger checks and balances, voters are better able to monitor what happens at the political level, respect for the rule of law is more widespread and so democratization should help reduce both lobbying and corruption". However, stronger democracy may give rise to lobbying groups which would be absent in autocratic regimes. Those lobbies can freely develop in a democracy such as in the U.S. where contributions for political parties are legal

\footnotetext{
${ }^{6}$ Those indicators are constructed using many different individual sources provided by different organizations.
} 
and widely accepted ${ }^{7}$ or in Europe through pressure groups. ${ }^{8}$ Nowadays, lobbies are seen in advanced democracies as a necessary connection between the civil society and the state.

Campos and Giovannoni (2008) empirically found that "firms that favor lobbying tend to be in countries that are more politically stable, more democratic, with more independent media ...". We can interpret those findings as a positive link between lobbying and governance indicators, which provide us with some appropriate instruments to signal the influence of interest groups. Other more direct variables to observe the influence of lobbying, such as campaign contributions, are only available for countries where lobbies are regulated (ex. the U.S.).

In our context of business taxation, lobbying groups are in general quite significant and influential (see Dreyfuss, 2001). They establish their presence in all democratic countries around the world in order to influence congressmen and to try to impose their reform agendas. We should expect that the actions of those pressure groups contribute to a drop in the corporate tax rate, as a signal of the benefits obtained. Otherwise their presence would be hard to justify and the market forces would have put an end to their industry a long time ago.

Lobbies target law-makers, but they need an appropriate institutional environment to operate and develop. As suggested by Kimenyi and Mbaku (1994) "Rent seeking accordingly takes different forms in democratic and autocratic regimes. In democratic systems lobbying of legislators can take place for different policies. In autocratic regimes, rule is in general protected by a military force, and the political elite has a privileged position in rent-seeking or rent-extracting behavior which would be compromised by democracy (...) Because rents in dictatorial systems are created primarily by the dictator's decrees and distributed by the ruler's handpicked appointees, lobbying of legislators is not an issue". Autocratic regimes could be normally characterized as short term rent seeking governments or as aiming to develop nationalistic entities. None of those governments will prioritize long-term policies in favor of business, such as tax cuts. ${ }^{9}$ There is evidence

\footnotetext{
${ }^{7}$ The role of campaign contributions on the US congress votes has been extensively analysed. It is in general assumed that the influence of the interest groups on politicians is carry out through donations to the political campaigns by political action committees, but also by placing lobbyists in Washington. See for instance Anson (2006).

${ }^{8}$ See for instance Bouwen (2003), McGrath (2002) or the Registers of Interest Representatives of the European Union.

${ }^{9}$ However we do not rule out that autocratic regime can implement short-term policies in favor of certain business groups such as monopoly licenses, preferential national steel purchases in time of crisis or similar measures.
} 
that autocracies limit trade (see Mansfield et al., 2000, Milner and Kubota, 2005, Aidt and Martin Gassebner, 2007) and economic freedom (Sturm and de Haan, 2003; Giavazzi and Tabellini, 2005), which goes against the objectives of the business community and free market principles. Therefore, we would expect that those governments most often produce higher corporate tax rates.

Another reason why we could observe higher taxes in countries with nationalist or religious governments is provided by Kai Konrad (2007). He suggests that countries may try to make the tax base immobile: "The activities include informative or persuasive advertising, political persuasion and influence, and effort that increases the value of the brand name of a country and enables policies that make investors or citizens loyal to this brand. These include educational effort that generates home attachment or even patriotism among the own population". Nationalist or religious governments are likely to be well designed to achieve such goals.

Besides governance factors, other institutional variables seem to ease lobbying activities. Campos and Giovannoni found that "firms that favor lobbying (...) are also more likely to be located in federal states, with presidential systems and, within presidential systems, where the president has fewer power. Within parliamentary systems, lobbying seems to be more effective where there are more constraints on the executive".

There is contrasting evidence on the link between federal states and corporate taxation and between federal states and lobbying. On the one hand, when provinces or states within a country have taxation powers, they can engage in a tax competition process which can lead to an overall lower tax burden for the country, as it is suggested by the case of Switzerland (see for instance, Feld and Reulier, 2005, though we cannot reject that other reasons may explain low tax rates in Switzerland). On the other hand, the same decentralization process can lead to administrative inefficiencies or yardstick competition in infrastructure and public good provision which demand additional resources and eventually a higher tax burden. A similar process can occur between federal states and lobbying. On the one hand, there is a general view that local governments are more susceptible to be captured by lobbies (see Bardhan and Mookherjee, 2000, Bordignon, Colombo and Galmarini, 2008, Redoano, 2007, Lockwood, 2005). Nevertheless, most literature has focused on the link between federalism and corruption instead of lobbying (see Fisman and Gatti, 2002, Freille, Haqueand and Kneller, 2007). 
In our view, ${ }^{10}$ lobbying looses effectiveness in federal states because politicians are limited in their commitment to defend a particular policy given that different levels of government can intervene. Therefore, we expect that federal countries have higher corporate tax rates.

The literature argues that parliamentary systems will reduce the incentive to lobby the legislature. For Bennedsen and Feldmann (2002) a parliamentary system will induce voting cohesion in the coalition in order to preserve the government and therefore, interest groups have fewer incentives to lobby. On the other hand, congressional systems do not have those constraints and interest groups may have more influence on legislators. Helpman and Person (2001) also highlight that parliamentary systems produce greater legislative cohesion and affects the strategic interaction with lobbies. In our context, we expect that parliamentary systems will in general have a higher corporate tax since the legislature will be less sensitive to business pressures.

\section{$2.2 \quad$ Political Factors}

Campos and Giovannoni find that fewer powers or more constraints on the executive facilitate lobbying. Measures of political power could be indicated by the margin of victory or parliamentary majority. Another indirect measure of power is the simple use of the electoral system. Following Duverger's principle, we know that a plurality rule election system will tend toward a two-party system, marginalizing small political parties. Hence, a single party will be more likely to hold the majority of seats in parliament and to have more power to pass legislation with less negotiation. On the other hand, a proportional representation system lets new parties to develop fast and the constant negotiation among the coalition reduces the power of the government.

Under those circumstances a plurality system can give more power to the executive, reduce the influence of lobbying and induce a higher corporate tax rate.

Other political factors affecting the corporate tax rate are partisanship and the electoral cycle. On these points, there is an abundant literature, but the articles reach different conclusions. A priori, it can be argued that left-wing parties increase the tax burden on firms and their owners; but on the other hand, it can be also argued that since a rise in corporate taxation reduces new investments and affects future employment, left-wing parties

\footnotetext{
${ }^{10}$ Campos and Giovannoni provide the same argument, but they arrive to a different conclusion.
} 
will prefer low tax burdens on firms. Beside the references already mentioned in the introduction the reader can find further discussion on these points in Quinn and Shapiro (1991a,b), Timmons (2005) and references therein.

\subsection{Economic Factors}

Many politicians and academic researchers believe that an increasing openness or globalization of the economies is leading countries to a race to the bottom in corporate taxation (European Commission, 2001). That idea supports the view that economic and competition reasons linked with free market are the main determinants of the corporate tax.

Among the domestic determinants of corporate taxation are normally considered country's revenue needs and factors affecting the mobility of the tax base - such as the size of the economy, the number of potential customers, or the country's openness.

On the other hand, there is now a huge literature claiming that tax and yardstick competition influence the local corporate tax. Yardstick competition explains that voters may evaluate the decision of their policy makers by comparing their actions with similar policies conducted in neighboring regions. Under those circumstances, governments may be forced to emulate each other leading to uniformity in taxes. Tax competition argues that in open economies "independent governments engage in wasteful competition for scarce capital through reductions in tax rates and public expenditure level" (Wilson, 1999). Nevertheless, both models arrive to the same conclusions: taxes depend on own countries characteristics and on neighboring countries tax rates.

\section{Empirical Investigation}

This section is dedicated to our empirical investigation. We first present the data set. Then we report on our empirical findings first using panel data without spatial lags, then taking into account the tax rates in neighboring countries.

\subsection{Data}

Thereafter, Table 1 lists the data series used in our empirical exercise and Table 2 provides the reader with the descriptive statistics for all variables. 


\subsubsection{The statutory corporate income tax rate}

Our dependent variable is the statutory corporate income tax rate. Effective tax rates such as the effective average tax rate (EATR) are not used in this paper mainly because of the amount of information we would need for to construct those variables in our set of $53^{11}$ or $93^{12}$ countries. Nevertheless, as pointed out in Ruiz and Gérard $(2007,2008)$ the changes in the EATRs are mainly due to changes in the statutory rate. ${ }^{13}$

For our panel estimation of Section 4, we take the period 1997-2008 with the statutory tax rates for 53 countries and the years 2007-2008 for 93 countries. ${ }^{14}$ We use tax data collected by KPMG. In the set of control variables we include governance, political and economic variables in order to capture the factors discussed above and deemed to influence the determination of the corporate tax rate. Additionally, in section 5, we take into account a possible design of strategic tax interactions among countries.

The statutory corporate tax is valued at the 1st of January of each year. Therefore all other explanatory variables are expressed at time -1 . For the few cases where data are missing, we consider that the variable has not changed from the last available observation.

\footnotetext{
${ }^{11}$ Argentina, Australia, Austria, Bangladesh, Belgium, Bolivia, Brazil, Canada, Chile, China, Colombia, Costa Rica, Czech Republic, Denmark, Dominican Republic, Ecuador, Fiji, Finland, France, Germany, Greece, Honduras, Hungary, Iceland, India, Indonesia, Ireland, Italy, Japan, South Korea, Luxemburg, Malaysia, Netherlands, New Zealand, Norway, Pakistan, Panama, Papua New Guinea, Paraguay, Peru, Philippines, Poland, Portugal, Singapore, Spain, Sri Lanka, Sweden, Switzerland, Thailand, Turkey, United Kingdom, United States, Vietnam.

${ }^{12}$ Albania, Argentina, Australia, Austria, Bahrain, Bangladesh, Barbados, Belarus, Belgium, Bolivia, Botswana, Brazil, Bulgaria, Canada, Chile, China, Colombia, Costa Rica, Croatia, Cyprus, Czech Republic, Denmark, Dominican Republic, Ecuador, Egypt, Estonia, Fiji, Finland, France, Germany, Greece, Guatemala, Honduras, Hungary, Iceland, India, Indonesia, Iran, Ireland, Israel, Italy, Jamaica, Japan, Jordan, Kazakhstan, South Korea, Kuwait, Latvia, Libya, Lithuania, Luxemburg, Malaysia, Malta, Mauritius, Mexico, Mozambique, Netherlands, New Zealand, Norway, Oman, Pakistan, Panama, Papua New Guinea, Paraguay, Peru, Philippines, Poland, Portugal, Qatar, Romania, Russia, Saudi Arabia, Singapore, Slovak Republic, Slovenia, South Africa, Spain, Sri Lanka, Sweden, Switzerland, Syria, Thailand, Tunisia, Turkey, Ukraine, United Arab Emirate, United Kingdom, United States, Uruguay, Venezuela, Vietnam, Yemen, Zambia.

${ }^{13}$ The corporate income tax rate for each country considers the federal (or unique tax) and an average of provincial, cantonal and communal taxes when it is applicable.

${ }^{14}$ The data set could be observed as too comprehensive for some readers, because of the different heterogeneous countries we use. However, all those countries have a business community that could influence the decision of the government, given the appropriate political circumstances.
} 


\subsubsection{Economic factors}

The first four explanatory variables are classical economic factors affecting the corporate tax rates; they come from the IMF.

The variable $c g d p$ is the part of government consumption in the GDP. It refers to what Slemrod calls the folk theorem among tax policymakers: "all taxes have weaknesses, and the marginal social cost of the weaknesses increases with the tax system's reliance on any given tax. Therefore, revenues should be collected from a variety of taxes rather than a small number". As an implication, if government spending increases, revenue needs to increase and corporate taxation should follow that tendency.

The relative size of the country's gross domestic product, $g d p p$, and that of its population, pop, aim to capture the size effect. Several theoretical models such as Bucovetsky (1991) analyze the effect of differences in the size of the competing countries, coming to the conclusion that the larger the country the higher the tax rates it chooses.

Openness variable, $o$, tries to see whether there is a link between openness of an economy and the corporate tax rate.

\subsubsection{Governance and political factors}

Most of our governance and political factors could be interpreted as instruments to signal the influence of interest groups, and we understand our empirical findings in that linethat. We once more repeat that other direct variables to observe the influence of lobbying, such as campaign contributions, are only available for countries where lobbies are regulated (ex. the U.S.).

The variable "voice and accountability", vacr, is a measure of governance proposed in the World Governance Indicators (WGI) project of the World Bank. The WGI also publishes measures of Political Stability and Absence of Violence, Government effectiveness, Regulatory Quality, Rule of Law, and Control of Corruption. However, all those indicators are highly correlated among them. For that reason, we have decided to select only one, Voice and Accountability which measures "perceptions of the extent to which a country's citizens are able to participate in selecting their government, as well as freedom of expression, freedom of association, and a free media". Following the discussion of section 2 we would expect that the better the governance indicators, the easier business lobbying groups develop, and therefore, the lower the corporate tax rate is.

Governance and political factors come from the Database of Political In- 
stitutions (DPI) of the World Bank. Variable sysp is the variable SYSTEM in the DPI, but with 1 for Parliamentary and Assembly-elected President and 0 for Presidential regime. We expect that a parliamentary system, especially when combined with a plurality voting rule - see below - reduces the power of the interest groups and therefore downward pressures on the corporate income tax rate.

Variable $r c$ is the variable EXECRLS in the DPI, but with 0 for Left and 1 for Right, Center, No information and No executive. We use this classification to clearly identify leftist parties (communist, socialist, social democratic, or left-wing). We already mentioned the lack of evidence in the literature for a clear link between a right-left variable and taxation, but $a$ priori we would expect that a left-wing government impulses higher taxes on enterprises.

The variables nat and $\mathrm{rel}$ are respectively the variable EXECNAT and EXECREL in the DPI. They indicate with 1 the countries where the executive is classified as nationalist or religious. We expect that those governments weaken lobbying groups, make the tax base less mobile and generate a higher corporate tax rate.

The fraction of seats held by the government is the variable MAJ in the DPI, and reflects the margin of majority of the government. We expect that a large margin of majority increases the power of the executive and reduces the power of lobbies.

Similar to the previous variable, we measure the power of the executive with one typical voting rule. The variable hous is equal to HOUSESYS in the DPI giving value 1 when a plurality voting system predominates in the House of Congress and when the Legislative and Executive Indices of Electoral Competitiveness liec is equal or smaller to 4. A plurality system will tend to concentrate power on two parties and we expect that this concentration of power on two parties - or on one party - reduces the action of business lobbying groups and preserves a higher corporate tax rate.

\subsubsection{EU and federation dummies}

The $E U$ variable is just a dummy showing the EU membership.

Finally, fed is a dummy variable indicating that a country is a federal state; in that matter we use the classification provided by the Forum of Federations (FF) and we add to it Papua New Guinea. 
Table 1: Description of variables

\begin{tabular}{|l|l|l|l|}
\hline Variable & \multicolumn{1}{|c|}{ Description } & Source & $\begin{array}{l}\text { Expected } \\
\text { sign }\end{array}$ \\
\hline$t$ & Statutory corporate income tax rate 1997-2008 & KPMG & \\
\hline$c g d p$ & Government Consumption / GDP & IMF & + \\
\hline gdpp & GDP / GDP US * 100 & IMF & + \\
\hline$o$ & Openess (Exp + Imp)/GDP & IMF & - \\
\hline pop & Population & IMF & + \\
\hline vacr & Voice and accountability & WGI & - \\
\hline sysp & Parliamentary 1 and presidential system 0 & DPI & + \\
\hline rc & 0 for left party (1 right, center, etc.) & DPI & - \\
\hline nat & nationalist party $=1$ & DPI & + \\
\hline rel & Religious executive $=1$ & DPI & + \\
\hline majp & Fraction of seats held by the government & DPI & + \\
\hline lege & Legislative election in the year & DPI & - \\
\hline hous & $\begin{array}{l}\text { Plurality system and no legislative 1(liec } \leq 4), \\
\text { proportional representation } 0\end{array}$ & DPI & + \\
\hline EU & EU member & DPI & - \\
\hline liec & Legislative indice of elec competiveness & DPI & \\
\hline fed & Federal countries 1 & FF & $?$ \\
\hline
\end{tabular}


Table 2: Descriptive statistics

\begin{tabular}{|c|l|l|l|l|l|}
\hline & \multicolumn{5}{|l|}{ Sample 1996-2007 (53 countries) } \\
\hline Variable & Mean & Median & Min & Max & SD \\
\hline$t$ & 30.78 & 30.00 & 57.50 & 10.00 & 6.763 \\
\hline$c g d p$ & 15.49 & 15.16 & 27.50 & 4.364 & 5.061 \\
\hline gdpp & 5.933 & 1.401 & 100.0 & 0.016 & 15.00 \\
\hline$o$ & 86.55 & 72.72 & 371.4 & 14.93 & 57.41 \\
\hline pop & 85.35 & 16.28 & 1329 & 0.270 & 225.2 \\
\hline vacr & 67.67 & 75.30 & 100.0 & 5.263 & 26.23 \\
\hline sysp & 0.667 & 1 & 1 & 0 & 0.472 \\
\hline rc & 0.657 & 1 & 1 & 0 & 0.475 \\
\hline nat & 0.066 & 0 & 1 & 0 & 0.249 \\
\hline rel & 0.116 & 0 & 1 & 0 & 0.321 \\
\hline \multicolumn{7}{|l}{} & \multicolumn{5}{l}{} \\
\hline \multicolumn{7}{|l|}{} & Sample $2006-2007(93$ countries) \\
\hline Variable & Mean & Median & Min & Max & SD \\
\hline$t$ & 29.83 & 30.00 & 57.50 & 0.000 & 7.719 \\
\hline cgdp & 15.86 & 15.81 & 28.84 & 4.364 & 5.129 \\
\hline gdpp & 4.545 & 0.964 & 100.0 & 0.016 & 12.99 \\
\hline$o$ & 88.21 & 76.22 & 371.4 & 14.93 & 52.02 \\
\hline pop & 67.40 & 11.12 & 1329 & 0.270 & 194.7 \\
\hline vacr & 63.55 & 66.83 & 100.0 & 1.923 & 26.89 \\
\hline sysp & 0.590 & 1 & 1 & 0 & 0.492 \\
\hline rc & 0.686 & 1 & 1 & 0 & 0.464 \\
\hline nat & 0.073 & 0 & 1 & 0 & 0.260 \\
\hline rel & 0.114 & 0 & 1 & 0 & 0.318 \\
\hline \multicolumn{7}{|l|}{}
\end{tabular}




\subsection{Panel estimation}

In this section we first estimate a classical panel data model without spatial lags. Then we estimate reaction functions of the interjurisdictional Nash non-cooperative game and thus introduce spatial lags. In Appendix A we examine the special case of EU membership and raise the question whether or not EU membership implies higher or lower corporate tax rates?

\subsubsection{Pooled cross-section estimation}

Let us begin by examining a classical panel data model. We consider a panel without and with time fixed effects. In the last part of the section we will present the results of a panel with spatial lag effects in order to observe possible strategic tax interactions among countries. Thus we estimate

$$
t_{i \iota}=\alpha+X_{i \iota} \theta+\epsilon_{i \iota}
$$

where $t$ is the tax rate, $\alpha$ and $\theta$ vector are parameters to be estimated and $\epsilon$ is the error term. ${ }^{15}$

Tables 3 and 4 show the results obtained with the statutory corporate tax rate as dependent variable and various sets of independent variables. Each column corresponds to a specification of the equation tested and provides the values of the coefficient estimated as well as the probability of being significantly different from zero.

The 1st column - column $(1)^{16}$ - ests forth the classical economic and demographic effects. All variables have the expected sign and are significant. We observe that countries which have higher consumption expenditures impose a higher corporate tax. The size variables $g d p p$ and $p o p$ support the idea that a large country may face a lower elasticity of capital to the tax rate, and therefore, sustain a higher tax. The $o$ result gives support to the argument that the openness of the economies is leading the countries to lower tax rates.

The 2nd column introduces the parliamentary system variable. We delete $c g d p$ and $p o p$ from the estimation because they are respectively positively and negatively correlated with the governance variables. ${ }^{17}$ A parliamentary system induces a higher corporate tax. We interpret that result as a lower power of lobbying groups due to the need of politicians to keep a permanent coalition on all pieces of legislation in order to preserve the government.

\footnotetext{
${ }^{15}$ That equation should be compared with equations (8) and (9) in Section 5.

${ }^{16}$ Columns are numbered across the two tables.

${ }^{17}$ Observe that although the effect of $c g d p$ and pop is captured by $s y s p$, the $R^{2}$ slightly increases, showing an improvement in the regression.
} 
The 3rd column considers the governance variable vacr. It shows that better governance seems to decrease the tax. This might reflect the fact that countries with better freedom of association and freedom of media, besides being perceived as more democratic, also permit the action and coordination of business lobbying groups.

The variables sysp and vacr are slightly correlated as suggested in column (4). For that reason, we will just consider sysp in the other estimations.

The 5th column shows that the right-left distinction is not a significant determinant of the corporate tax.

Column (6) considers nationalist and religious executives. Clearly, they are significant determinants and their coefficients are relatively high. Countries with a nationalist executive have a corporate tax approximately 3 points higher than other countries and for governments with a religious executive the effect if even higher. In our opinion those results reflect the power of the executive to impose its agenda, and to generate national attachment among the business community.

Column (7) shows that the fraction of seats held by the government is not a significant determinant of the corporate tax rate.

Column (8) shows the absence of a cyclical adjustment of the corporate taxation related to legislative elections.

Column (9) suggests that a plurality voting system or a concentration of power on two or one party may constraint the freedom of lobbying.

Column (10) reflects that nationalist executives and plurality system are significant in the absence of the rel variable.

Column (11) shows that when the system is of parliamentary type but one party is probably enough to sustain the government or when there is just one party in the parliament, the power of the executive increases and constraints lobbying activity.

The 12th column shows that federal states have a positive effect on corporate taxation. That result goes in the opposite direction of the paper of Campos and Giovannoni. However, in their article only two countries, Bosnia and Russia, can be considered as federal state following the classification of the Forum of Federations. Moreover, our findings support the idea that in federal states lobbying looses effectiveness because politicians are limited in their degree of commitment to defend a particular policy given that different levels of government can intervene.

Column (13) sets forth that the EU membership implies a higher corporate tax. This result may seem paradoxical given that KPMG's report 
Table 3: Results

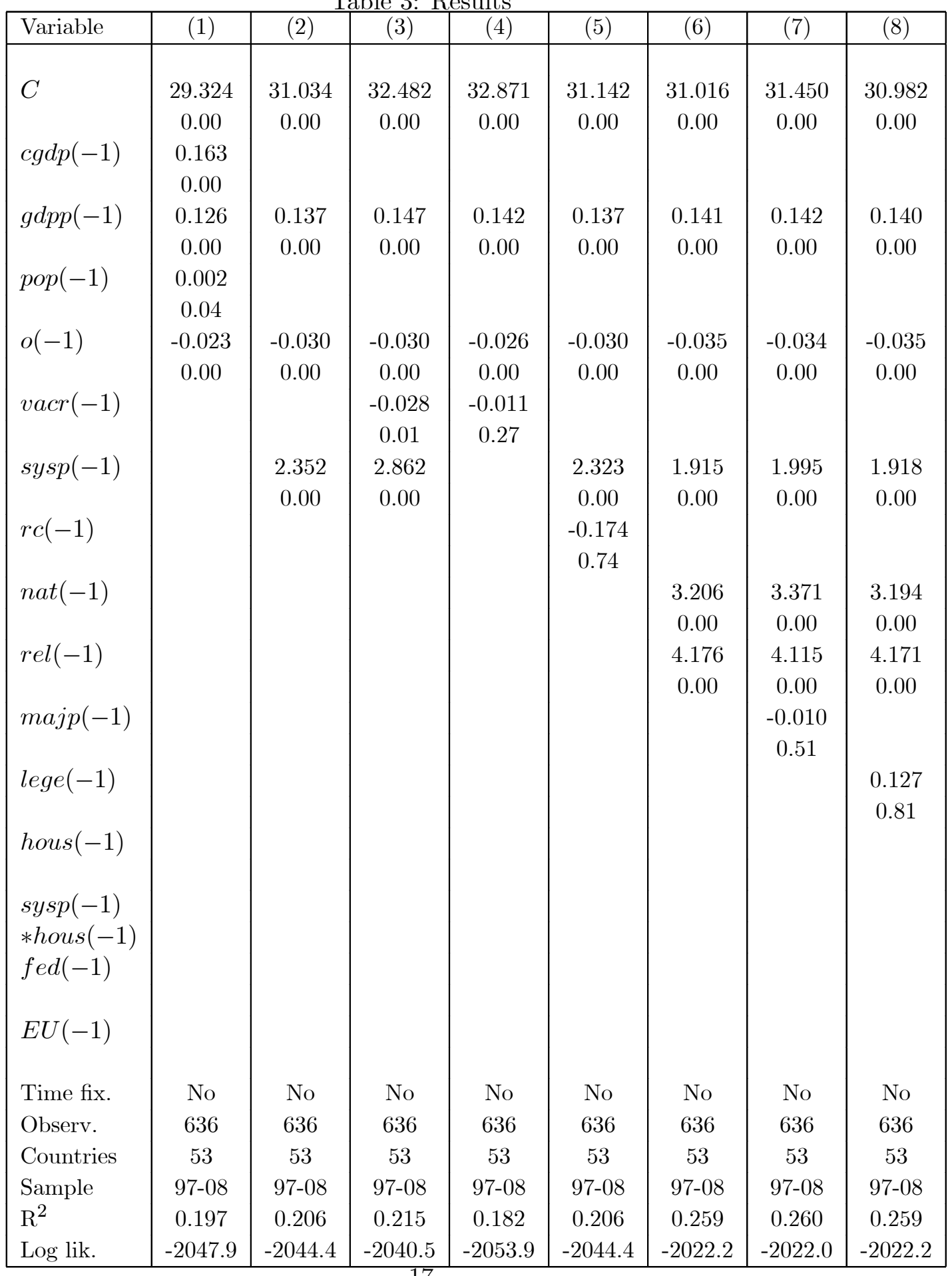


Table 4: Results

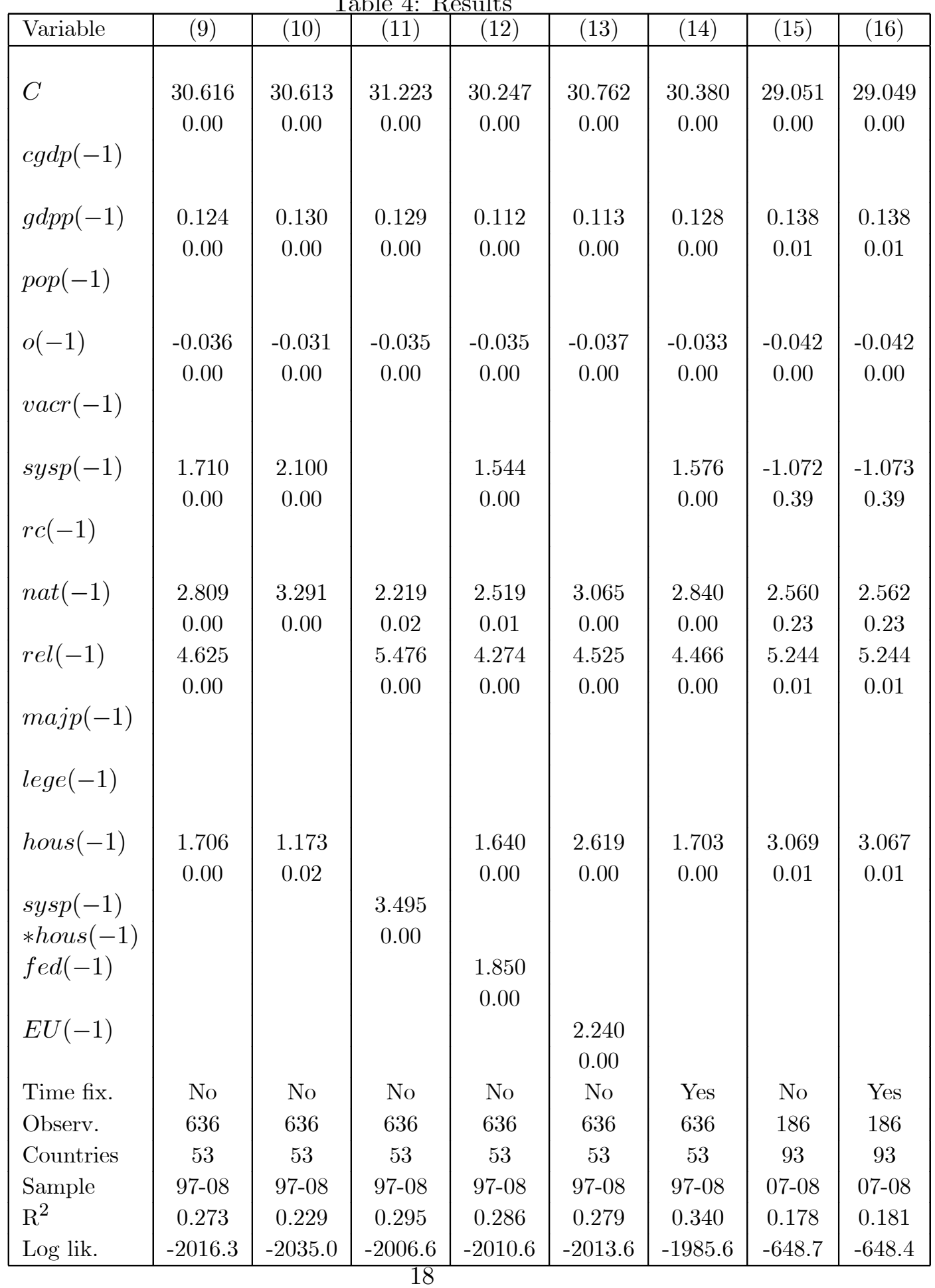


shows a clear fall in the corporate income tax rate if the EU. We examine more carefully that dummy variable in Appendix A.

Column (14) shows that the introduction of time fixed effects does not change the results.

Columns (15) and (16) show that in a shorter period of time but with more country observations, the parliamentary system and nationalist executive variables are no longer significant. However, the economic variables of size and openness are still significant and, what is more important for this article, the variables rel and hous which reflect to a certain extent a concentration of power, have a positive impact on the level of the corporate tax.

\subsubsection{Do countries play Nash equilibrium strategies in tax rates?}

In this last part of the section we try to capture corporate tax interactions among countries. The basic result of the tax competition literature states that the local capital tax rate should react positively to tax changes in competing countries, see below equations (6) and (7). The classical approach for empirically testing this assumption has been to estimate tax reaction functions (see Brueckner, 2003). Those reaction functions triy to capture how the magnitude of a tax, a decision variable for a government, depends on taxes set by other countries. In other words, the equation to be estimated might be written

$$
t_{i \iota}=\alpha+\beta \sum_{j \neq i} \varpi_{i j} t_{, \iota}+X_{i \iota} \theta+\epsilon_{i \iota}
$$

where $t$ is the tax rate, $\alpha, \beta$ and $\theta$ vector are parameters to be estimated and $\epsilon$ is the error term. Additionally, we assign weights $\varpi_{i j}$ indicating the possible influence of neighboring taxes in the determination of the local $\operatorname{tax}^{18}$

The second term on the RHS of equation (2) is referred to as the spatially lagged dependent variable, with associated autoregressive parameter $\beta$. If the slope of the estimated reaction function is non-zero we can speak of a strategic interaction among governments.

Weighting schemes Uncertainty with respect to the proper specification of the spatial weights matrix is a fundamental problem in the study of strate-

\footnotetext{
${ }^{18}$ Problems related to the estimation of equation (2), notably the endogeneity of $t_{j}$ 's and possible spatial error dependence, are discusssed in Anselin (1988) and in Ruiz and Gérard (2008).
} 
gic interactions, especially because we do not know exactly the structure of the international pressures. A potential problem of drawing inappropriate conclusions arises, as the specified weight matrix may not be the true weight matrix. In other words, detecting a priori the correct links among countries for tax settings purposes (if any) raises problems. Clearly choosing different weights is likely to result in different estimations of $\beta$.

Here, we will base our estimations on geographical weights. Those weights are the most widely used in the literature because they rely on the idea that geographical distance factors are relevant in the economy and that competition is more likely to occur among close neighbors.

Equation (2) is estimated using three weighting matrices, each of them being row standardized such that the

$$
\sum_{j=1}^{n} \varpi_{i j}=1
$$

The first weighting matrix considers as neighbors all countries of the sample and the weights are simply the inverse distance. A second weighting scheme assigns an inverse distance weight to those countries within a distance-band $\delta$ required to ensure that each location has at least one neighbor, i.e.

$$
\begin{aligned}
\varpi_{i j} & =\left(1 / d_{i j}\right) / \sum_{j=1}^{n}\left(1 / d_{i j}\right) \text { if } d_{i j} \leq \delta \\
& =0 \text { if } d_{i j}>\delta
\end{aligned}
$$

The third weighting matrix gives an equal weight to those countries within the distance-band explained before.

Pooled cross-section estimation with spatial lags: results The reduced form equation (2) is estimated using maximum likelihood methods, in the Matlab package developed by Elhorst (see Appendix B). ${ }^{19}$

The results are presented in Tables 6 and 7. The first column of each table repeats the results obtained above, without spatial lag - columns (9) and

\footnotetext{
${ }^{19}$ It is well known that the OLS estimator in the presence of spatially lagged dependent variable will be biased as well as inconsistent. Two methods are usually used to deal with this problem. The first one is to estimate the reduced form equation using maximum likelihood methods. The second way is an instrumental variable or two stage least squares approach. Anselin (1988) also proposes Bayesian techniques instrumented among others by LeSage (1997).
} 
(15) respectively; those figures are included to allow for an easy comparison and to show consistency among the various estimations. The discussion of our explanatory variables has been already provided in Section 2, and, as we can see, their effects do not vary across the various spatial associations. On the other hand, the parameter $\beta$ is the coefficient we are interested in this section; it represents the level of interdependence or competitive pressures that countries face when setting their corporate income tax rate.

The table shows some evidence of tax interdependency, although the results are not robust with respect to the specification of the model. Observing the results for 53 countries without time fixed effects, we do find evidence of strategic interactions. This may suggest that countries are mimicking taxes of their close neighbors. ${ }^{20}$

However, with the introduction of time fixed effects this pattern disappears. That may indicate that countries are following a general trend that is independent of geographical location. Even more, for 93 countries - the second part of the Table - and the sole years 2007-2008, we do not find any evidence of strategic interactions.

Summing up, our findings indicate that strategic tax interactions among close geographical neighbors are not the main reason affecting the corporate tax.

\footnotetext{
${ }^{20}$ Similar results were also found by Devereux, Lockwood and Redoano (2002) and by Redoano (2003).
} 
Table 5: Results Spatial Lags: 53 countries

\begin{tabular}{|c|c|c|c|c|c|c|c|}
\hline Variable & (9) & Inv. Dist & weight & Inv. Min & weight & Eq. Min & weight \\
\hline \multirow[t]{2}{*}{ C } & 30.616 & 16.569 & & 22.944 & & 21.898 & \\
\hline & 0.00 & 0.00 & & 0.00 & & 0.00 & \\
\hline \multirow[t]{2}{*}{$g d p p(-1)$} & 0.124 & 0.128 & 0.128 & 0.109 & 0.126 & 0.105 & 0.124 \\
\hline & 0.00 & 0.00 & 0.00 & 0.00 & 0.00 & 0.00 & 0.00 \\
\hline \multirow[t]{2}{*}{$o(-1)$} & -0.036 & -0.035 & -0.033 & -0.037 & -0.033 & -0.036 & -0.033 \\
\hline & 0.00 & 0.00 & 0.00 & 0.00 & 0.00 & 0.00 & 0.00 \\
\hline \multirow[t]{2}{*}{$\operatorname{sysp}(-1)$} & 1.710 & 1.446 & 1.598 & 1.557 & 1.558 & 1.454 & 1.528 \\
\hline & 0.00 & 0.00 & 0.00 & 0.00 & 0.00 & 0.00 & 0.00 \\
\hline \multirow[t]{2}{*}{ nat $(-1)$} & 2.809 & 3.034 & 2.815 & 3.286 & 2.915 & 3.212 & 2.931 \\
\hline & 0.00 & 0.00 & 0.00 & 0.00 & 0.00 & 0.00 & 0.00 \\
\hline \multirow[t]{2}{*}{$\operatorname{rel}(-1)$} & 4.625 & 4.280 & 4.494 & 4.382 & 4.436 & 4.550 & 4.464 \\
\hline & 0.00 & 0.00 & 0.00 & 0.00 & 0.00 & 0.00 & 0.00 \\
\hline \multirow[t]{2}{*}{ hous $(-1)$} & 1.706 & 1.502 & 1.726 & 1.362 & 1.649 & 1.312 & 1.614 \\
\hline & 0.00 & 0.00 & 0.00 & 0.01 & 0.00 & 0.01 & 0.00 \\
\hline \multirow[t]{2}{*}{$\varpi_{i j} t$} & & 0.463 & -0.055 & 0.259 & 0.041 & 0.298 & 0.068 \\
\hline & & 0.00 & 0.67 & 0.00 & 0.47 & 0.00 & 0.27 \\
\hline Time fix. & No & No & Yes & No & Yes & No & Yes \\
\hline Observ. & 636 & 636 & 636 & 636 & 636 & 636 & 636 \\
\hline Countries & 53 & 53 & 53 & 53 & 53 & 53 & 53 \\
\hline Sample & $97-08$ & $97-08$ & $97-08$ & $97-08$ & $97-08$ & $97-08$ & $97-08$ \\
\hline $\mathrm{R}^{2}$ & 0.2727 & 0.3195 & 0.3400 & 0.3024 & 0.3403 & 0.3084 & 0.3411 \\
\hline Log lik. & -2016.32 & -1999.07 & -1985.52 & -2006.80 & -1985.40 & -2004.68 & -1985.14 \\
\hline
\end{tabular}


Table 6: Results Spatial Lags: 93 countries

\begin{tabular}{|l|c|cc|cc|cc|}
\hline Variable & $(15)$ & Inv. Dist. weight & Inv. Min. weight & Eq. Min. weight \\
\hline & & & & & & & \\
& 29.051 & 30.416 & & 30.451 & & 27.774 & \\
gdpp $(-1)$ & 0.00 & 0.00 & & 0.00 & & 0.00 & \\
& 0.138 & 0.138 & 0.138 & 0.139 & 0.140 & 0.137 & 0.137 \\
o(-1) & 0.01 & 0.01 & 0.01 & 0.01 & 0.01 & 0.01 & 0.01 \\
& -0.042 & -0.042 & -0.042 & -0.042 & -0.042 & -0.042 & -0.042 \\
sysp $(-1)$ & 0.00 & 0.00 & 0.00 & 0.00 & 0.00 & 0.00 & 0.00 \\
& -1.072 & -1.102 & -1.133 & -1.089 & -1.095 & -1.072 & -1.073 \\
nat $(-1)$ & 0.39 & 0.36 & 0.35 & 0.37 & 0.36 & 0.37 & 0.37 \\
& 2.560 & 2.562 & 2.567 & 2.562 & 2.564 & 2.563 & 2.564 \\
rel $(-1)$ & 0.23 & 0.22 & 0.22 & 0.22 & 0.22 & 0.22 & 0.22 \\
& 5.244 & 5.241 & 5.238 & 5.227 & 5.223 & 5.299 & 5.284 \\
hous $(-1)$ & 0.01 & 0.01 & 0.01 & 0.01 & 0.01 & 0.01 & 0.01 \\
& 3.069 & 3.128 & 3.185 & 3.214 & 3.253 & 2.963 & 2.990 \\
$\varpi_{i j} t$ & 0.01 & 0.01 & 0.01 & 0.01 & 0.01 & 0.01 & 0.01 \\
& & -0.05 & -0.10 & -0.054 & -0.069 & 0.049 & 0.036 \\
& & 0.87 & 0.74 & 0.70 & 0.62 & 0.74 & 0.81 \\
Time fix. & No & No & Yes & No & Yes & No & Yes \\
Observ. & 186 & 186 & 186 & 186 & 186 & 186 & 186 \\
Countries & 93 & 93 & 93 & 93 & 93 & 93 & 93 \\
Sample & $07-08$ & $07-08$ & $07-08$ & $07-08$ & $07-08$ & $07-08$ & $07-08$ \\
$\mathrm{R}^{2}$ & 0.1779 & 0.1781 & 0.1813 & 0.1787 & 0.1818 & 0.1784 & 0.1808 \\
Log lik. & -648.71 & -648.69 & -648.35 & -648.64 & -648.31 & -648.66 & -648.39 \\
\hline
\end{tabular}

\section{Theoretical modeling}

In this section we suggest a theoretical exercise which extends standard tax competition modeling through the introduction of government lobbying by the multinational. Doing so we provide theoretical foundations for the empirical exercise conducted in the previous section. Our first attempt lies in Grossman and Helpman (1994) tradition, which refers to Bernheim and Whinston (1986), an approach also used by Conconi (1998), Marceau and Smart (2003) and Mahle and Runkel (2009). The second attempt follows Lorz (1998). Before addressing the lobbying issue we present the reference model corresponding to the situation without lobbying. 


\subsection{A world without lobbying}

Suppose, like in Gérard (2007), a two-country-one-multinational model where the two countries compete for attracting the real capital of the multinational. That game follows a two-step pattern. In the first step the governments decide non-cooperatively of the tax rates - we make no distinction between statutory and effective tax rate; in the second step the multinational revises the location of its real capital. We solve the problem backward.

\subsubsection{Step 2, the multinational}

The multinational aims at maximizing its value. Therefore, given the tax rates announced by the governments, it reallocates its real capital. However such reallocation has a cost deemed to obey a quadratic form. The total amount of real capital of the multinational is normalized to unity with initially a fraction $\alpha_{0}$ located in country $a$ and a fraction $1-\alpha_{0}$ located in country $b$; after reallocation, those fractions are $\alpha$ and $1-\alpha$ respectively. Formally the MNE, or multinational enterprise, maximizes

$$
V=\frac{p}{r}-\tau_{a} \alpha \frac{p}{r}-\tau_{b}(1-\alpha) \frac{p}{r}-\frac{\gamma}{2}\left(\alpha-\alpha_{0}\right)^{2}
$$

In that equation, $p$ stands for the EBITDA (Earnings before Interest payments, Taxes and Depreciation Allowances) of the multinational. The first order condition of that maximization w.r.t. $\alpha$ is ${ }^{21}$

$$
\frac{d V}{d \alpha}=\left(\tau_{b}-\tau_{a}\right) \frac{p}{r}-\gamma\left(\alpha-\alpha_{0}\right)=0
$$

so that optimal distribution of investment is characterized by

$$
\alpha=\alpha_{0}+\left(\tau_{b}-\tau_{a}\right) \frac{p}{\gamma r}
$$

\subsubsection{Step 1: the local governments decide on the tax rates}

Each local government decides on the corporate tax rate on the profit of the multinational on its territory. It takes its decision in order to maximize an objective function based on the positive effects that the location and the investment of the multinational is expected to have in the region in terms of economic activity, denoted by $w \alpha$ for region $a$, with $w$ the shadow price of labor, and on the quantity of public goods that taxing the multinational will allow it to provide to its inhabitants, $u \tau_{a} \alpha p / r$ again for region $a ; u$ is the

${ }^{21}$ The second order condition, $-\gamma<0$, is satisfied. 
shadow price of public goods, thus the cost of transforming private income into public goods, the size of that cost is interpreted as a sign of government inefficiency. It turns out that the local government of region $a$ maximizes a social welfare function

$$
W_{a}=w \alpha+u \tau_{a} \alpha \frac{p}{r}
$$

Using equation (4), the first order condition of that maximization is ${ }^{22}$

$$
\frac{d W_{a}}{d \tau_{a}}=u\left[\alpha_{0}+\left(\tau_{b}-\tau_{a}\right) \frac{p}{\gamma r}\right] \frac{p}{r}-\frac{w}{\gamma} \frac{p}{r}-u \frac{\tau_{a}}{\gamma}\left(\frac{p}{r}\right)^{2}=0
$$

so that we obtain the reaction function

$$
\tau_{a}=\frac{u \gamma \alpha_{0}-w}{2 u} \frac{r}{p}+\frac{\tau_{b}}{2}
$$

where we observe that the slope of the reaction function is well smaller than one.

Similarly, the reaction function of the other country is

$$
\tau_{b}=\frac{u\left(1-\alpha_{0}\right) \gamma-w}{2 u} \frac{r}{p}+\frac{\tau_{a}}{2}
$$

At this stage it is worth noticing that

$$
\begin{aligned}
\frac{d \tau_{a}}{d \alpha_{0}} & =\frac{\gamma}{2} \frac{r}{p}>0 \\
\frac{d \tau_{a}}{d \gamma} & =\frac{\alpha_{0}}{2} \frac{r}{p}>0
\end{aligned}
$$

so that both the size of the fraction of the investment initially hold by the country and that of the cost of changing the interjurisdictional distribution of the whole investment - the inverse of the openness - push the tax rate upward.

Since the former might depend on the size on the local market, we can interpret those comparative statics results as meaning that a larger region might have a relatively higher corporate income tax rate, and that reducing the obstacles to the free movement of (real) capital pushes the tax rates downward. It turns out that the reaction functions obtained above provide us with theoretical foundations for empirical equation (2).

\footnotetext{
${ }^{22}$ The derivative of $V$ w.r.t. $\tau_{a}$ is $-\alpha p r$. That of $\alpha$ w.r.t. $\tau_{a}$ is $-p / \gamma r$. The second order condition of that maximization is $-(u-s)(1 / \gamma)(p / r)^{2}<0$.
} 
For the purposes of an empirical analysis, the set of those two reaction functions gives the structural form of the model, not however the reduced form. That latter is obtained by computing the Nash equilibrium, solving for the tax rates in the system consisting of equations (6) and (7),

$$
\tau_{a}=\frac{1+\alpha_{0}}{3} \frac{\gamma r}{p}-\frac{w}{u} \frac{r}{p}
$$

and similarly

$$
\tau_{b}=\frac{1+\left(1-\alpha_{0}\right)}{3} \frac{\gamma r}{p}-\frac{w}{u} \frac{r}{p}
$$

and provides theoretical support for equation (1) of the empirical investigation conducted above.

As previously suggested the values of the tax rates at the Nash equilibrium increases with $\alpha_{0}$ in $a$ and with $1-\alpha_{0}$ in $b$, and with $\gamma$ in both countries. Moreover the tax rate decreases when government inefficiency cost $u$ goes down, see e.g. for country $a$

$$
\frac{d \tau_{a}}{d u} \propto(3 u-2 s)^{2} \frac{w}{\gamma}+(u-s) s(4 u-2 s)+\alpha_{0} u^{2} s>0
$$

Eventually, at the equilibrium without lobbying

$$
\begin{aligned}
\alpha & =\frac{1+\alpha_{0}}{3} \\
1-\alpha & =\frac{2-\alpha_{0}}{3}
\end{aligned}
$$

and

$$
\begin{aligned}
& W_{a}=u \alpha^{2} \gamma=u\left(\frac{1+\alpha_{0}}{3}\right)^{2} \gamma \\
& W_{b}=u(1-\alpha)^{2} \gamma=u\left(\frac{2-\alpha_{0}}{3}\right)^{2} \gamma
\end{aligned}
$$

Now let us see how the reaction functions, the distribution of investment and the levels of social welfare are affected by lobbying activities. 


\subsection{A world with lobbying multinational: Grossman-Helpman tradition}

In this world the multinational is ready to pay an amount of money to each government in exchange of a more favorable tax rate; and governments are deemed not only to maximize the social welfare of their country residents but also to pursue the best interest of the multinational in exchange of contributions.

Let us start with Grossman-Helpman (1994) Proposition 1, adapted to our model; they refer it as B-W for Bernheim and Whinston (1986). Then a subgame-perfect Nash equilibrium might be characterized by

(a) $C_{a}$ and $C_{b}$ contributions of the multinational to the respective governments are feasible, by which is meant non negative and consistent with firm's value;

(b) $\tau_{a}^{L}$ maximizes $G_{a}=W_{a}+\sigma_{a} C_{a}$ where $\sigma_{a}$ stands for the weight given by the government to a contribution of the multinational enterprise, an indicator of its sensitiveness to lobbying; and similarly for the other country;

(c) $\tau_{a}^{L}$ maximizes $\Omega+W_{a}+\sigma_{a} C_{a}$, with $\Omega=V-C_{a}-C_{b}$, the value of the firm net of its contributions to the governments.

In that framework, step 2 of the previous game becomes step 3. Step 1 becomes step 2 and a new step 1 is introduced where the firm decides on its contribution to the governments. Actually the new step 3 replicates the former step 2 and equation (4) holds.

\subsubsection{Step 2: determination of the tax rates}

According to (b) of Grossman-Helpman Proposition 1, the government of country a maximizes $W_{a}+\sigma_{a} C_{a}$. In line with (c) of the same proposition $\tau_{a}^{L}$ also maximizes $\Omega+W_{a}+\sigma_{a} C_{a}$. It turns out that

$$
\frac{d W_{a}}{d \tau_{a}^{L}}+\sigma_{a} \frac{d C_{a}}{d \tau_{a}^{L}}=0
$$

and simultaneously

$$
\frac{d V}{d \tau_{a}^{L}}-\frac{d C_{a}}{d \tau_{a}^{L}}+\frac{d W_{a}}{d \tau_{a}^{L}}+\sigma_{a} \frac{d C_{a}}{d \tau_{a}^{L}}=0
$$


However the multinational, if allowed to decide on the tax rate levied by country $a$ will choose that rate such that it maximizes its value, so that

$$
\frac{d V}{d \tau_{a}^{L}}-\frac{d C_{a}}{d \tau_{a}^{L}}=0
$$

Therefore satisfying (b) and (c) simultaneously calls for the first order condition

$$
\frac{d W_{a}}{d \tau_{a}^{L}}+\sigma_{a} \frac{d V}{d \tau_{a}^{L}}=0
$$

which provides the reaction function

$$
\tau_{a}^{L}=\frac{\left(u-\sigma_{a}\right) \gamma \alpha_{0}-w}{2 u-\sigma_{a}} \frac{r}{p}+\frac{u-\sigma_{a}}{2 u-\sigma_{a}} \frac{\tau_{b}}{2}
$$

and similarly for the other country

$$
\tau_{b}^{L}=\frac{\left(u-\sigma_{b}\right)\left(1-\alpha_{0}\right) \gamma-w}{2 u-\sigma_{b}} \frac{r}{p}+\frac{u-\sigma_{b}}{2 u-\sigma_{b}} \frac{\tau_{a}}{2}
$$

so that tax rates at Nash equilibrium become

$$
\tau_{a}^{L}=\frac{\theta_{b}+\left(1-\theta_{b}\right) \alpha_{0}}{1-\theta_{a} \theta_{b}} \theta_{a} \frac{\gamma r}{p}-\frac{w_{a}}{1-\theta_{a} \theta_{b}}-\frac{\theta_{b} w_{b}}{1-\theta_{a} \theta_{b}}
$$

and

$$
\tau_{b}^{L}=\frac{\theta_{a}+\left(1-\theta_{a}\right)\left(1-\alpha_{0}\right)}{1-\theta_{a} \theta_{b}} \theta_{b} \frac{\gamma r}{p}-\frac{w_{b}}{1-\theta_{a} \theta_{b}}-\frac{\theta_{a} w_{a}}{1-\theta_{a} \theta_{b}}
$$

respectively, where

$$
\theta_{a}=\frac{u-\sigma_{a}}{2 u-\sigma_{a}} ; \theta_{b}=\frac{u-\sigma_{b}}{2 u-\sigma_{b}}
$$

and

$$
w_{a}=\frac{w}{2 u-\sigma_{a}} \frac{r}{p} ; w_{b}=\frac{w}{2 u-\sigma_{b}} \frac{r}{p}
$$

A first lesson from that exercise is that an increased sensitiveness of the government of, say, country $a$ to lobbying from the multinational pushes the corporate tax rate downward in that country since

$$
\frac{d \tau_{a}^{L}}{d \sigma_{a}}=\frac{\tau_{a}^{L}}{1-\theta_{a} \theta_{b}} \frac{d \theta_{a}}{d \sigma_{a}}<0
$$

However that response to lobbying depends on the sensitiveness of the other country too since $\theta_{b}$ depends on $\sigma_{b}$. 
Using equations (14) and (15) we can compute the equilibrium values of $\alpha^{L}, W_{a}^{L}$ and $W_{b}^{L}$. Let us do that for countries equally open to lobbying activities $\left(\theta_{a}=\theta_{b}=\theta, \sigma_{a}=\sigma_{b}=\sigma\right)$; then

$$
\alpha^{L}=\frac{\theta+(1-\theta) \alpha_{0}}{1+\theta}=\frac{u-\sigma+u \alpha_{0}}{3 u-2 \sigma}
$$

and

$$
W_{a}^{L}=(u-\sigma) \gamma\left(\alpha^{L}\right)^{2}=(u-\sigma) \gamma\left(\frac{u-\sigma+u \alpha_{0}}{3 u-2 \sigma}\right)^{2}
$$

and similarly for the other country. We verify that

$$
\frac{d W_{a}^{L}}{d \sigma}<0
$$

provided that $u>3 \sigma$ which seems to be a reasonable assumption. That last observation makes a link with the next issue: the determination of the political contributions.

Under the same assumption we also have that

$$
\tau_{a}^{L}=\frac{\gamma r}{u p}\left(1+u \alpha_{0}\right) \frac{u-\sigma}{3 u-2 \sigma}-\frac{w r}{u p}<\tau_{a}
$$

\subsubsection{Step 3: Political contributions}

In line with Marceau and Smart (2003) equation (8) we can define the political contribution of the multinational to the government of country $a$ (viz. of country $b$ ) as the minimum amount the multinational has to pay for that government being at least as well off though adopting the tax rates favorable to the firm. Therefore the optimal contribution $C_{a}$ is such that

$$
\sigma_{a} C_{a}=W_{a}-W_{a}^{L}
$$

using equations (11) and (18).

Under the assumption that the countries are equally open to lobbying, that latter equation implies

$$
C_{a}=\frac{\gamma}{\sigma}\left[u\left(\frac{1+\alpha_{0}}{3}\right)^{2}-(u-\sigma)\left(\frac{u-\sigma+u \alpha_{0}}{3 u-2 \sigma}\right)^{2}\right]
$$




\subsection{A world with a lobbying multinational: alternative ap- proach (Lorz, 1998)}

Let us keep the basic model unchanged; in Lorz (1998) terminology it corresponds to countries ruled by capital-poor government. The capital-abundant party or simply the multinational, will try to turn the social welfare function maximized by governments into one more favorable to them through the addition of a term $\sigma_{a} V$ (viz. $\sigma_{b} V$ ). However the value of $\sigma_{a}$ will increase with that of the political contribution paid to the government of country $a$, $C_{a}$.

Therefore step 1 and step 2 repeat those encountered in the GrossmanHelpman tradition, but with now $\sigma$ contingent to $C$. Step 3 is then reformulated as the maximization by the multinational of $V-C_{a}-C_{b}$ w.r.t. to $\sigma_{a}$ and $\sigma_{b}$. Let us do that with respect to the former assuming again that the two governments are equally responsive to political contributions. The first order condition of the maximization is then

$$
\frac{d V}{d \tau_{a}} \frac{d \tau_{a}}{d \sigma_{a}}-\frac{d C_{a}}{d \sigma_{a}}=0
$$

and we follow Lorz(1998) assuming that political contribution have a diminishing marginal productivity, thus that the marginal cost of lobbying is increasing; let therefore

$$
C_{a}=\frac{\phi_{a}}{2}\left(\sigma_{a}\right)^{2}
$$

We know that

$$
\begin{aligned}
\frac{d V}{d \tau_{a}} & =-\alpha=-\frac{u-\sigma+u \alpha_{0}}{3 u-2 \sigma} \\
\frac{d \tau_{a}}{d \sigma_{a}} & =-\frac{\gamma r}{u p} \frac{\left(1+u \alpha_{0}\right) \sigma}{(3 u-2 \sigma)^{2}}
\end{aligned}
$$

Then the first order condition becomes, under our simplifying assumption,

$$
\frac{u-\sigma+u \alpha_{0}}{3 u-2 \sigma} \frac{\gamma r}{u p} \frac{\left(1+u \alpha_{0}\right) \sigma}{(3 u-2 \sigma)^{2}}=\phi \sigma
$$

Solving for $\sigma$ and using the definition of $C$ provide us with the optimal political contribution of the multinational. 


\section{Conclusions}

The results of our estimation suggest that next to the classical economic factors of size and openness of an economy, and strategic interactions among countries as well, political and institutional variables matter for determining the statutory corporate tax rate. In particular we find that countries with good governance indicators have a lower tax rate; and that a parliamentary system combined with a plurality voting rule increases the tax rate. Additionally, countries with religious or nationalist executives are also characterized by higher tax rates.

Our conclusions are in line with Campos and Giovannoni (2008): like in their contribution, the political and institutional factors that we found to be significant also set forth the presence of stronger lobbying activities. In other words, the political and institutional variables we find significant in our study could be interpreted as instruments for the presence of lobbies in a country.

The result suggesting that nationalist executives allow for higher rates might be related to Konrad (2007) hypothesis that countries may generate home attachment to keep and tax mobile resources.

Theoretical grounds for those findings and interpretation can be found in Grossman-Helpman tradition of taking into account lobbying and political contributions. Therefore we expanded our supporting theoretical model in that direction.

\section{References}

[1] T. Aidt and M. Gassebner. Do Autocratic States Trade Less? Cambridge Economics Working Paper No. 0742, 2007.

[2] R. Altshuler and T. Goodspeed. Follow the leader? Evidence on European and US tax competition. mimeo, 2002.

[3] L. Anselin. Spatial Econometrics: Methods and Models. Kluwer Academic Publishers, 1988.

[4] J. Anson. "Intra-Industry Competition for Political Influence: An Empirical Investigation of U.S. Steel Industry Firms' Lobbying". 2006.

[5] P. Bardhan and D. Mookherjee. Capture and governance at local and national levels. American Economic Review, 90 (2), 135-139, 2000. 
[6] B. Bernheim and M. Whinston. Menu auctions, Resource Allocation, and Economic Influence. Quarterly Journal of Economics. 101 (1): 1-31, 1986 .

[7] T. Besley, R. Griffith, and A. Klemm. Empirical evidence on fiscal interdependence in OECD countries. Mimeograph, 2001.

[8] M. Bennedsen and S. Feldmann. Lobbying Legislatures. Journal of Political Economy, 110, 41, 2002.

[9] M. Bordignon, L. Colombo and U. Galmarini. Fiscal federalism and lobbying. Journal of Public Economics, 92, 2288-2301, 2008.

[10] P. Bouwen. The Logic of Access to the European Parliament: Business Lobbying in the Committee on Economic and Monetary Affairs. Journal of Common Market Studies, Volume 42, 3: 473-95, 2004.

[11] J. Brueckner. Strategic interaction among governments: An overview of empirical studies. Regional Science Review, 26:175-188, 2003.

[12] S. Bucovetsky. Asymmetric tax competition. Journal of Urban Economics, 30(2):167-81, 1991.

[13] N. Campos and F. Giovannoni. Lobbying, corruption and political influence. Public Choice, 131: 1-21, 2007.

[14] N. Campos and F. Giovannoni. Lobbying, corruption and Other Banes. IZA DP No. 3693, 2008.

[15] A. Cassette and S. Paty. Tax Competition Among Eastern and Western European Countries: With Whom Do Countries Compete? Economic Systems, Vol. 32, No. 4, 2008.

[16] P. Conconi. Green lobbies and transboundary pollution in large open economies. Journal of International Economics, 59: 399-422, 1998.

[17] K. Crabbé and H. Vandenbussche. Are your firm's taxes set in Warsaw? Spatial tax competition in Europe. CORE Discussion Paper 2008/81, 2008.

[18] M. Devereux, B. Lockwood, and M. Redoano. Do countries compete over corporate tax rates? CEPR Discussion Paper, 3400, 2002. 
[19] M. Devereux, B. Lockwood, and M. Redoano. Do countries compete over corporate tax rates? Journal of Public Economics, vol. 92(5-6): 1210-1235, 2008.

[20] R. Dreyfuss. Grover Norquist: 'Field Marshal' of the Bush Plan. The Nation. May 14, 2001.

[21] European Commission. Company taxation in the internal market. Technical Report 582, European Commission, 2001.

[22] R. Fisman and R. Gatti, Decentralization and corruption: evidence across countries. Journal of Public Economics, Volume 83 (3), 325-345, 2002 .

[23] L. Feld and E. Reulier. Strategic Tax Competition in Switzerland: Evidence from a Panel of the Swiss Cantons. CESifo Working Paper Series No. 1516, 2005.

[24] S. Freille, M. Haque and R. Kneller. Federalism, Decentralisation and Corruption. 2007.

[25] S. Ganghof and P. Genschel. Taxation and Democracy in the EU. MPIfG Discussion Paper 07/2, 2007.

[26] G. Garrett. Global markets and national policies: Collision course or virtous cycle. International Organization, 52 (4):787-824, 1998.

[27] M. Gérard. Reforming the Taxation of Multijurisdictional Enterprises in Europe. CESifo Economic Studies, 53 (2): 329-361, 2007.

[28] F. Giavazzi and G. Tabellini. Economic and political liberalizations. Journal of Monetary Economics, 52, 1297-1330, 2005.

[29] P. Gomes and F. Pouget. Corporate Tax Competition and the Decline of Public Investment. CESifo Working Paper Series No. 2384, 2008.

[30] G. Grossman and E. Helpman. Protection for Sale. Amercian Economic Review, 84 (4): 833-850, 1994.

[31] J. Haan and J.-E. Sturm. Does more democracy lead to greater economic freedom? New evidence for developing countries. European Journal of Political Economy, 19, 547-563, 2003.

[32] S. Hahm, M. Kamlet and D. Mowery. Influences on deficit spending in industrialized countries. Journal of Public Policy, 15, 183-197, 1995. 
[33] E. Helpman and T. Persson. Lobbying and Legislative Bargaining. Advances in Economic Analysis and Policy, 1, 2001.

[34] J. Hindriks and G. Myles. Intermediate Public Economics. MIT Press, 2006.

[35] P. Hirst. Democracy and Governance. In Debating Governance. Edited by Jon Pierre. Oxford University Press. 2000.

[36] IRS. Corporation Income Tax Brackets and Rates, 1909-2002. Data Release. 2002.

[37] D. Kaufmann, A. Kraay, Aart and P. Zoido. Governance Matters. World Bank Policy Research Working Paper No. 2196. 1999.

[38] M. Kimenyi and J. Mbaku. Rents, military elites, and political democracy. European Journal of Political Economy, Vol. 11, 699-708, 1995.

[39] K. Konrad. Mobile Tax Base as a Global Common. CESifo Working Paper No. 2144, 2007.

[40] Q. Li. Democracy, Autocracy, and Tax Incentives to Foreign Direct Investors: A Cross-National Analysis. The Journal of Politics, Vol. 68, $1,2006$.

[41] B. Lockwood. Fiscal Decentralization: A Political Economy Perspective. Warwick Economic Research Papers, 721, 2005.

[42] Lorz, O. Capital mobility, tax competition, and lobbying for redistributive capital taxation. European Journal of Political Economics, 14: 265-270, 1998 .

[43] A. Mahle and M. Runkel. Corporate Income Taxation and Lobbying of Multinational Enterprises. Mimeo, 2009.

[44] E. Mansfield, H. Milner and B. Rosendorff. Free to Trade: Democracies, Autocracies and International Trade. American Political Science Review, 94(2): 305-321, 2000.

[45] N. Marceau and M. Smart. Corporate Lobbying and Commitment Failure in Capital Taxation. American Economic Review, 93 (1): 241-251, 2003. 
[46] H. Milner and K. Kubota. Why the Move to Free Trade? Democracy and Trade Policy in the Developing Countries. International Organization 59, 2005.

[47] C. McGrath. Comparative Lobbying Practices: Washington, London, Brussels. University of Ulster. 2002.

[48] D. Quinn. The correlates of change in international financial regulation. American Political Science Review, 91:531-551, 1997.

[49] D. Quinn and R. Shapiro. Economic Growth Strategies: The Effects of Ideological Partisanship on Interest Rates and Business Taxation in the United States. American Journal of Political Science, 35: 656-85, 1991a.

[50] D. Quinn and R. Shapiro. Business Political Power: The Case of Taxation. American Political Science Review, 85 (3): 851-874, 1991b.

[51] M. Redoano. Fiscal interactions among European countries. Warwick Economic Research Papers, 680, 2003.

[52] M. Redoano. Does centralization affect the number and size of lobbies? CESifo Working Paper No. 1968, 2007.

[53] D. Rodrik. Has Globalization Gone Too Far. Institute for International Economics, 1997.

[54] F. Ruiz and M. Gérard. Is there evidence of strategic corporate tax interaction among EU countries? MPRA Paper No. 10094, 2008.

[55] F. Ruiz and M. Gérard. Summary, description, extensions of the capital income effective tax rate literature. Elsevier: International Taxation Handbook, chapter 2, 11-42, 2007.

[56] J. Slemrod. Are corporate tax rates, or countries, converging? Journal of Public Economics, 88:1169-1186, 2004.

[57] D. Swank and S. Steinmo. The new political economy of taxation in advance capitalist democracies. American Journal of Political Science, 46 (3):671-692, 2002.

[58] J. Tavares. Does right or left matter? cabinets, credibility and fiscal adjustments. Journal of Public Economics, 88:2447-2468, 2004. 
[59] J. Timmons. Left, Right and Center: Partisanship, taxes and the welfare state. Annual Meeting of the American Political Science Association, 2005.

[60] J. Wilson. Theories of tax competition. National Tax Journal, 52:269304, 1999.

[61] H. Winner. Hax tax competition emerged in OECD countries? Evidence from panel data. International Tax and Public Finance, 12 (5):667-687, 2005. 
Table 7: EU dummy

\begin{tabular}{|c|c|c|c|c|c|c|c|}
\hline & \multicolumn{5}{|c|}{$1997-2008$} & \multicolumn{2}{|c|}{$2007-2008$} \\
\hline & (1) & (2) & (3) & (4) & (5) & (6) & $(7)$ \\
\hline \multirow[t]{2}{*}{ c } & 30.384 & 30.321 & 32.656 & 31.677 & 30.100 & 28.415 & 27.081 \\
\hline & $(0,00)^{a}$ & $(0,00)^{a}$ & $(0,00)^{a}$ & $(0,00)^{a}$ & $(0,00)^{a}$ & $(0,00)^{a}$ & $(0,00)^{a}$ \\
\hline \multirow[t]{2}{*}{$\mathrm{EU}(-1)$} & 1.319 & 1.528 & -6.208 & -2.965 & & -4.282 & \\
\hline & $(0.02)^{b}$ & $(0.01)^{a}$ & $(0,00)^{a}$ & $(0.02)^{b}$ & & $(0.00)^{a}$ & \\
\hline EU15 (-1) & & & & & 2.411 & & 0.850 \\
\hline Country fix & No & No & Yes & Yes & No & No & No \\
\hline Time fixed & No & Yes & No & Yes & No & No & No \\
\hline Observ. & 636 & 636 & 636 & 636 & 636 & 186 & 186 \\
\hline $\mathrm{R}^{2}$ & 0.008 & 0.095 & 0.703 & 0.779 & 0.026 & 0.049 & 0.001 \\
\hline Log lik. & -2115.0 & -2085.8 & -1732.1 & -1638.0 & -2109.3 & -662.3 & -666.8 \\
\hline $\begin{array}{l}\mathrm{p} \text {-values are } \\
{ }^{a} \text { Significant } \\
{ }^{b} \text { Significant }\end{array}$ & $\begin{array}{l}\text { n parentl } \\
\text { at } 1 \% \text { lev } \\
\text { at } 5 \% \text { lev }\end{array}$ & eses & & & & & \\
\hline
\end{tabular}

\section{Appendix A. Does EU membership imply higher or lower corporate tax rates?}

We could be tempted to argue that the EU integration has increased the competition among Member states and therefore has forced them to reduce their tax rates. However, is that true? Is it only a responsibility of the European Union? As depicted below, it seems that it is not the case. Let us show what would be the result introducing only a dummy for the EU in our regression.

The first column in Table 7 shows that the corporate tax rate for the countries belonging to the EU was 1.32 points higher than for the rest of the 53 countries during the same period ( 31.70 for EU countries against 30.38 for non-EU countries in average). However, observing the third column we can see that the three EU countries that joined the Union during that period (in our sample we have only three such countries, the Czech Republic, Hungary and Poland) decreased their tax rates of 6.21 on average after joining the Union. Nevertheless, this value is smaller after controlling for the negative time trend that all countries faced. When we just observe the average of EU15 in the 5th column we see that the tax was 2.41 higher for those countries. 
Nevertheless, those results are clearly influenced by the data sample and no consideration is given to the other nine new Member states of the EU which have very low corporate tax rates. The second part of the Table shows that during the last 2 years, the EU countries had, on average, a corporate tax rate 4.28 lower than the rest of the 93 countries. And, last column, the corporate tax rate of the EU15 in the last two years was just above the average, although with large heterogeneity among countries.

\section{Appendix B}

Writing (2) in matrix form

$$
\tau=\beta W \tau+X \theta+\epsilon
$$

The log-likelihood function corresponding to equation (2) is:

$$
\begin{aligned}
L(\tau, \theta, \beta, \sigma)= & -\frac{N T}{2} \ln (2 \pi)-\frac{N T}{2} \ln \sigma^{2}+\ln |I-\beta W| \\
& -\frac{1}{2 \sigma^{2}}[(I-\beta W) \tau-X \theta]^{\prime}[(I-\beta W) \tau-X \theta]
\end{aligned}
$$

with $\tau$ as a $N T \times 1$ vector, $X$ as a $N T \times K$ matrix, $W$ the full $N T \times N T$ weights matrix, $I$ the full $N T \times N T$ identity matrix and $\epsilon \sim I I D\left(0, \sigma^{2} I\right)$.

Given a block diagonal structure $\left|I_{T} \otimes\left(I_{N}-\beta W_{N}\right)\right|$ for the determinant, it simplifies to

$$
\begin{aligned}
L(\tau, \theta, \beta, \sigma)= & -\frac{N T}{2} \ln (2 \pi)-\frac{N T}{2} \ln \sigma^{2}+T \ln \left|I_{N}-\beta W_{N}\right| \\
& -\frac{1}{2 \sigma^{2}}[(I-\beta W) \tau-X \theta]^{\prime}[(I-\beta W) \tau-X \theta]
\end{aligned}
$$

where $W_{N}$ is the $N \times N$ weights matrix.

A two-stage procedure can be used to maximize the log-likelihood function of the model (see Anselin 1988, p. 181-182, Anselin and Hudak 1992, Elhorst 2003).

The fist order condition of the maximization of equation (21) provides us with an estimator

$$
\widetilde{\theta}=\left(X^{\prime} X\right)^{-1} X^{\prime}(I-\beta W) \tau
$$

or

$$
\begin{aligned}
\widetilde{\theta} & =\left(X^{\prime} X\right)^{-1} X^{\prime} \tau-\beta\left(X^{\prime} X\right)^{-1} X^{\prime} W \tau \\
& =\widetilde{\theta}_{0}-\beta \widetilde{\theta}_{L}
\end{aligned}
$$


The two coefficient vectors will provide two sets of residuals

$$
\begin{aligned}
e_{0} & =\tau-X \widetilde{\theta}_{0} \\
e_{L} & =W \tau-X \widetilde{\theta}_{L}
\end{aligned}
$$

Differentiating the log-likelihood function with respect to $\sigma$ and putting the derivative equal to zero yields

$$
\begin{gathered}
\frac{\partial L}{\partial \sigma}=-\frac{N T}{\sigma}+\frac{1}{\sigma^{3}}[(I-\beta W) \tau-X \theta]^{\prime}[(I-\beta W) \tau-X \theta]=0 \\
\widehat{\sigma^{2}(\beta, \theta)}=\frac{1}{N T}[(I-\beta W) \tau-X \theta]^{\prime}[(I-\beta W) \tau-X \theta]
\end{gathered}
$$

Taking into account the auxiliary residuals yields

$$
\widehat{\sigma^{2}(\beta)}=\frac{1}{N T}\left(e_{0}-\beta e_{L}\right)^{\prime}\left(e_{0}-\beta e_{L}\right)
$$

Substituting $\widehat{\sigma^{2}(\beta)}$ into $(21)$ results in a concentrated likelihood function of the form

$$
L(\beta)=C-\frac{N T}{2} \ln \left[\frac{1}{N T}\left(e_{0}-\beta e_{L}\right)^{\prime}\left(e_{0}-\beta e_{L}\right)\right]+T \ln |I-\beta W|-\frac{N T}{2}
$$

That expression is a nonlinear function in $\beta$ that can be maximized by means of numerical techniques.

The estimation process proposed by Anselin (1988) and implemented in the Matlab package of Elhorst consists to

- Carry out OLS of $X$ on $\tau$ : yields $\widetilde{\theta}_{0}$.

- Carry out OLS of $X$ on $W \tau$ : yields $\widetilde{\theta}_{L}$.

- Compute the residuals $e_{0}$ and $e_{L}$.

- Given $e_{0}$ and $e_{L}$, find $\beta$ that maximizes $L$.

- Given $\beta$, compute $\widetilde{\theta}$ and $\widehat{\sigma^{2}}$. 


\section{CESifo Working Paper Series}

for full list see www.cesifo-group.org/wp

(address: Poschingerstr. 5, 81679 Munich, Germany, office@cesifo.de)

2841 Andreas Knabe, Steffen Rätzel and Stephan L. Thomsen, Right-Wing Extremism and the Well-Being of Immigrants, October 2009

2842 Andrea Weber and Christine Zulehner, Competition and Gender Prejudice: Are Discriminatory Employers Doomed to Fail?, November 2009

2843 Hadi Salehi Esfahani, Kamiar Mohaddes and M. Hashem Pesaran, Oil Exports and the Iranian Economy, November 2009

2844 Ruediger Bachmann and Christian Bayer, Firm-Specific Productivity Risk over the Business Cycle: Facts and Aggregate Implications, November 2009

2845 Guglielmo Maria Caporale, Burcu Erdogan and Vladimir Kuzin, Testing for Convergence in Stock Markets: A Non-Linear Factor Approach, November 2009

2846 Michèle Belot and Jan Fidrmuc, Anthropometry of Love - Height and Gender Asymmetries in Interethnic Marriages, November 2009

2847 Volker Nitsch and Nikolaus Wolf, Tear Down this Wall: On the Persistence of Borders in Trade, November 2009

2848 Jan K. Brueckner and Stef Proost, Carve-Outs Under Airline Antitrust Immunity, November 2009

2849 Margarita Katsimi and Vassilis Sarantides, The Impact of Fiscal Policy on Profits, November 2009

2850 Scott Alan Carson, The Relationship between Stature and Insolation: Evidence from Soldiers and Prisoners, November 2009

2851 Horst Raff and Joachim Wagner, Intra-Industry Adjustment to Import Competition: Theory and Application to the German Clothing Industry, November 2009

2852 Erkki Koskela, Impacts of Labor Taxation with Perfectly and Imperfectly Competitive Labor Markets under Flexible Outsourcing, November 2009

2853 Cletus C. Coughlin and Dennis Novy, Is the International Border Effect Larger than the Domestic Border Effect? Evidence from U.S. Trade, November 2009

2854 Johannes Becker and Clemens Fuest, Source versus Residence Based Taxation with International Mergers and Acquisitions, November 2009

2855 Andreas Hoffmann and Gunther Schnabl, A Vicious Cycle of Manias, Crashes and Asymmetric Policy Responses - An Overinvestment View, November 2009 
2856 Xavier Vives, Strategic Supply Function Competition with Private Information, November 2009

2857 M. Hashem Pesaran and Paolo Zaffaroni, Optimality and Diversifiability of Mean Variance and Arbitrage Pricing Portfolios, November 2009

2858 Davide Sala, Philipp J.H. Schröder and Erdal Yalcin, Market Access through Bound Tariffs, November 2009

2859 Ben J. Heijdra and Pim Heijnen, Environmental Policy and the Macroeconomy under Shallow-Lake Dynamics, November 2009

2860 Enrico Spolaore, National Borders, Conflict and Peace, November 2009

2861 Nina Czernich, Oliver Falck, Tobias Kretschmer and Ludger Woessmann, Broadband Infrastructure and Economic Growth, December 2009

2862 Evžen Kočenda and Martin Vojtek, Default Predictors and Credit Scoring Models for Retail Banking, December 2009

2863 Christian Gollier and Martin L. Weitzman, How Should the Distant Future be Discounted when Discount Rates are Uncertain?, December 2009

2864 Tiberiu Dragu and Mattias Polborn, Terrorism Prevention and Electoral Accountability, December 2009

2865 Torfinn Harding and Beata Smarzynska Javorcik, A Touch of Sophistication: FDI and Unit Values of Exports, December 2009

2866 Matthias Dischinger and Nadine Riedel, There's no Place like Home: The Profitability Gap between Headquarters and their Foreign Subsidiaries, December 2009

2867 Andreas Haufler and Frank Stähler, Tax Competition in a Simple Model with Heterogeneous Firms: How Larger Markets Reduce Profit Taxes, December 2009

2868 Steinar Holden, Do Choices Affect Preferences? Some Doubts and New Evidence, December 2009

2869 Alberto Asquer, On the many Ways Europeanization Matters: The Implementation of the Water Reform in Italy (1994-2006), December 2009

2870 Choudhry Tanveer Shehzad and Jakob De Haan, Financial Reform and Banking Crises, December 2009

2871 Annette Alstadsæter and Hans Henrik Sievertsen, The Consumption Value of Higher Education, December 2009

2872 Chris van Klaveren, Bernard van Praag and Henriette Maassen van den Brink, Collective Labor Supply of Native Dutch and Immigrant Households in the Netherlands, December 2009 
2873 Burkhard Heer and Alfred Maußner, Computation of Business-Cycle Models with the Generalized Schur Method, December 2009

2874 Carlo Carraro, Enrica De Cian and Massimo Tavoni, Human Capital Formation and Global Warming Mitigation: Evidence from an Integrated Assessment Model, December 2009

2875 André Grimaud, Gilles Lafforgue and Bertrand Magné, Climate Change Mitigation Options and Directed Technical Change: A Decentralized Equilibrium Analysis, December 2009

2876 Angel de la Fuente, A Mixed Splicing Procedure for Economic Time Series, December 2009

2877 Martin Schlotter, Guido Schwerdt and Ludger Woessmann, Econometric Methods for Causal Evaluation of Education Policies and Practices: A Non-Technical Guide, December 2009

2878 Mathias Dolls, Clemens Fuest and Andreas Peichl, Automatic Stabilizers and Economic Crisis: US vs. Europe, December 2009

2879 Tom Karkinsky and Nadine Riedel, Corporate Taxation and the Choice of Patent Location within Multinational Firms, December 2009

2880 Kai A. Konrad, Florian Morath and Wieland Müller, Taxation and Market Power, December 2009

2881 Marko Koethenbuerger and Michael Stimmelmayr, Corporate Taxation and Corporate Governance, December 2009

2882 Gebhard Kirchgässner, The Lost Popularity Function: Are Unemployment and Inflation no longer Relevant for the Behaviour of Germany Voters?, December 2009

2883 Marianna Belloc and Ugo Pagano, Politics-Business Interaction Paths, December 2009

2884 Wolfgang Buchholz, Richard Cornes and Dirk Rübbelke, Existence and Warr Neutrality for Matching Equilibria in a Public Good Economy: An Aggregative Game Approach, December 2009

2885 Charles A.E. Goodhart, Carolina Osorio and Dimitrios P. Tsomocos, Analysis of Monetary Policy and Financial Stability: A New Paradigm, December 2009

2886 Thomas Aronsson and Erkki Koskela, Outsourcing, Public Input Provision and Policy Cooperation, December 2009

2887 Andreas Ortmann, "The Way in which an Experiment is Conducted is Unbelievably Important": On the Experimentation Practices of Economists and Psychologists, December 2009 
2888 Andreas Irmen, Population Aging and the Direction of Technical Change, December 2009

2889 Wolf-Heimo Grieben and Fuat Şener, Labor Unions, Globalization, and Mercantilism, December 2009

2890 Conny Wunsch, Optimal Use of Labor Market Policies: The Role of Job Search Assistance, December 2009

2891 Claudia Buch, Cathérine Tahmee Koch and Michael Kötter, Margins of International Banking: Is there a Productivity Pecking Order in Banking, too?, December 2009

2892 Shafik Hebous and Alfons J. Weichenrieder, Debt Financing and Sharp Currency Depreciations: Wholly vs. Partially Owned Multinational Affiliates, December 2009

2893 Johannes Binswanger and Daniel Schunk, What is an Adequate Standard of Living during Retirement?, December 2009

2894 Armin Falk and James J. Heckman, Lab Experiments are a Major Source of Knowledge in the Social Sciences, December 2009

2895 Hartmut Egger and Daniel Etzel, The Impact of Trade on Employment, Welfare, and Income Distribution in Unionized General Oligopolistic Equilibrium, December 2009

2896 Julian Rauchdobler, Rupert Sausgruber and Jean-Robert Tyran, Voting on Thresholds for Public Goods: Experimental Evidence, December 2009

2897 Michael McBride and Stergios Skaperdas, Conflict, Settlement, and the Shadow of the Future, December 2009

2898 Ben J. Heijdra and Laurie S. M. Reijnders, Economic Growth and Longevity Risk with Adverse Selection, December 2009

2899 Johannes Becker, Taxation of Foreign Profits with Heterogeneous Multinational Firms, December 2009

2900 Douglas Gale and Piero Gottardi, Illiquidity and Under-Valuation of Firms, December 2009

2901 Donatella Gatti, Christophe Rault and Anne-Gaël Vaubourg, Unemployment and Finance: How do Financial and Labour Market Factors Interact?, December 2009

2902 Arno Riedl, Behavioral and Experimental Economics Can Inform Public Policy: Some Thoughts, December 2009

2903 Wilhelm K. Kohler and Marcel Smolka, Global Sourcing Decisions and Firm Productivity: Evidence from Spain, December 2009

2904 Marcel Gérard and Fernando M. M. Ruiz, Corporate Taxation and the Impact of Governance, Political and Economic Factors, December 2009 